\title{
The Relationship among Demotivating Factors, Gender, Educational Fields, and Reading Proficiency: A Study of Iranian EFL Learners
}

\section{Narjes Ghafournia $^{1^{*}}$ \& Zahra Farhadian ${ }^{1}$}

\author{
* Correspondence: \\ narjesghafournia@yahoo.com \\ ${ }^{1}$ Department of English, Neyshabur \\ Branch, Islamic Azad University, \\ Neyshabur, Iran
}

Received: 9 July 2018

Revision: 3 August 3, 2018

Accepted: 20 September 2018

Published online: 20 December 2018

\begin{abstract}
The study explored the probable significant relationship among demotivating factors, gender, educational fields, and reading proficiency of Iranian EFL learners. The participants in this study were 96 Iranian high school students, learning English as a foreign language (EFL). They were high school female and male students between 16 to 18 years of age. There was the initial population of over 150 students. A stratified random sampling procedure was used to have three groups of 32 from the three educational fields. Each group comprised 16 females and 16 males. There was a Persian questionnaire, which surveyed participants' judgment on each demotivating factor in the process of language learning. Another instrument used in this study was the reading section of Cambridge Test of English Proficiency. The ex post facto design was used in this study. The findings revealed a significant relationship between the participants' reading proficiency and language learning demotivating factors. The findings also showed a significant relationship between the participants' educational fields and the demotivating factors. No significant relationship was found between the participants' gender and demotivating factors. The findings also revealed that the participants reduced self-confidence and lack of inadequate school facilities and teachers are the most salient demotivating factors. The findings of the study have some pedagogical implications to improve teacher-training programs and language teaching paradigms.
\end{abstract}

Keywords: demotivating factors, educational field, reading proficiency, motivating factors 


\section{Introduction}

Individual differences such as attitudes, expectations, motivation, and affective states have significant roles in foreign language learning process. Among affective states, demotivation, test anxiety, and foreign language classroom anxiety are salient constructs in the field of psychology. In Second Language Acquisition (SLA) research, motivation is viewed as a key factor in language learning. There is a widespread recognition that motivation is of great importance for successful L2 acquisition, but there is less agreement about what motivation actually consists of. Each individual student in each of the three main study fields of science, humanities, and math may exhibit different orientations in terms of the factors involved in their motivation and in those factors that demotivate them. Gender has been widely studied in this regard in western educational communities. There is lack of enough reliable evidence concerning gender and motivation.

Since the late $60 \mathrm{~s}$ and early $70 \mathrm{~s}$, there has been a significant shift within the field of language learning and teaching with greater emphasis on learners and learning rather than on teachers and teaching. Learner autonomy is in line with current views on the active involvement of learners, popularity of learner-centered approaches, and learners' independence of teachers (Littlewood, 1996). The quality and quantity of an individual's motivation can change over time and can be influenced by external factors. SLA research views motivation as a key factor in L2 learning. There have been differences, however, in the way in which teachers and researchers have typically conceptualized motivation (Crookes \& Schmidt, 1991).

There is a widespread recognition that motivation is of great importance for successful L2 acquisition. As Dörnyei (2007) asserts, the motivating character of the learning context can be enhanced through conscious intervention by the language teacher. However, there is less agreement about what motivation actually consists of. Among the models presented to account for motivation in educational setting is that of Zoltán Dörnyei (2001) has appealed more to language teaching practitioners. In his seminal book, Motivational Strategies in the Language Classroom (2001), Dörnyei set up a framework to describe motivation through three stages. These stages have to do with building and maintaining motivation through the course of learning the language.

Motivation has been shown to be a crucial factor for determining the success of second/ foreign language acquisition (Dornyei, 2001; Oxford \& Shearin, 1994; Scarcella \& Oxford, 1992; Warden \& Lin, 2000). However, there are also demotivating factors, which impede learners' learning motivation and lead to unsuccessful mastery of English language proficiency. According to Gorham and Christophel (1992) and Christophel and Gorham (1995), two-thirds of the demotivating factors, pertinent to instructional communication, have to do with "teacher." Falout et al. (2009, p.46) believed that "demotivation can negatively influence the learner's attitudes and behaviors, degrade classroom dynamics and teacher's motivation, and result in long-term and negative outcomes." As time passes, language learners lose their motivation to learn a language and are becoming more demotivated. Hence, the number of demotivated learners is increasing. In the context of Iranian general education, reading proficiency is highlighted, more than other skills. In fact, the main goal of the English textbooks is to develop students' reading proficiency. They are hoped to develop a reading proficiency so that they may have a chance to pursue their studies at higher levels of education. Therefore, if they fail to gain this ability in high school, they will be afflicted by a lack of ability in reading English, unless such impeding factors are overcome in the classroom. This study addresses issues like demotivation, gender, and educational fields as potential determining factors in reading proficiency.

The lack or withdrawal of motivation on the part of the learners is the main theme of this study. Demotivation is a new issue in the field of second language motivation. Among the factors that may lead to demotivation, teacher-related issues have been more frequently reported. Dornyei (2001) stated that demotivation does not mean that all the positive influences that originally made up the motivational basis of a behavior have been annulled; rather, it is only the resultant force that has been dampened by a strong negative component. "Demotivation" concerns specific external forces that reduce or diminish the motivational basis of a behavioral intention or an ongoing action. A demotivated learner is someone who was once motivated but has lost his or her commitment/interest for some reasons. Some other issues that have been mentioned in the literature as demotivating factors are learning difficulties, class settings, anxiety, management, etc.

In an ideal world, where the learners' curiosity and inherent motivation have not as yet been curbed or diminished by a student-unfriendly school system, all learners are eager to learn, and the learning experience is a constant source of intrinsic pleasure for them. However, instead of all those keen pupils, who according to the theory, should be eagerly absorbing the morsels of wisdom offered to them, language teachers see rather reluctant youngsters, who are totally 
unaware of the fact that there should be an innate curiosity in them, let alone a desire to learn (Dörnyei, 2001). In Iranian educational context, English is among the courses that are not welcome by the students, and when they are asked, their answer is or seems to be straightforward, "We don't understand it"! This lack of comprehension is another issue among the demotivating factors. The reason why they think this way most probably has roots in one or more of the demotivating factors found in the literature; however, the statement that teacher is a major demotivator seems to bear hints of exaggeration. In some cases, there is a sound rapport among a teacher and students; however, the students do not favor learning English.

As English language teaching gains more importance throughout the world, special attention should be given to implementing new teaching methods dealing with an appreciation towards the students' individuality and uniqueness. Thus, in this study, demotivating factors in reading comprehension are investigated in terms of gender and educational fields, which have been rarely explored in the previous studies.

\subsection{Research Questions}

This study tries to answer the following questions:

1. Is there any significant relationship between Iranian EFL learners' reading proficiency and their demotivating factors to learn English?

2. Is there any significant relationship between Iranian EFL learners' educational fields and their demotivating factors to learn English?

3. Is there any significant relationship between Iranian EFL learners' gender and their demotivating factors to learn English?

\subsection{Research Hypotheses}

In order to investigate the above questions, the following null hypotheses are stated:

Ho1: There is no significant relationship between Iranian EFL learners' reading proficiency and their demotivating factors to learn English.

Ho2: There is no significant relationship between Iranian EFL learners' educational fields and their demotivating factors to learn English.

$\mathbf{H}_{\mathbf{0 3}}$ : There is no significant relationship between Iranian EFL learners' gender and their demotivating factors to learn English.

\section{Review of the Literature}

Just like motivation, demotivation is an important factor in language learning. By demotivation we mean states or conditions that hinder a person from doing his or her best in achieving a specific purpose. Some regard demotivation similar to amotivation. However, some scholars like Dörnyei (2001) make a distinction between these two. He argued that "amotivation indicates a lack of motivation brought about by the realization that 'there is no point.' Thus, amotivation is related to general outcome anticipations that are usually considered to be unrealistic, whereas demotivation is pertaining to specific external causes (p.17). Amotivated people feel a lack of competence or control over their external environments, a feeling of helplessness caused by lack of contingency between behaviors and outcomes (Vallerand \& Ratelle, 2002).

Dörnyei (2001) also defined demotivation as "specific external forces that reduce or diminish the motivational basis of a behavioral intention or an ongoing action" (p.143). He identified several factors that could hinder learners' motivation including negative experiences with current and previous teachers, poor school facilities and materials, low self-confidence, bad opinions of the second language or its culture, negative attitudes of other group members, and the fact that language study is compulsory. In comparison with motivation, the number of studies on learners' demotivation is very limited. Kikuchi and Sakai (2009) focused on specific external forces that may decrease Japanese high school students' motivation. They collected data through questionnaire administration and found five factors related to students' demotivation: course books, inadequate school facilities, test scores, non-communicative methods, and teachers' competence and teaching styles. 
In Iranian educational context, the study of demotivation is still in its beginning stage. Heidari, Soureshjani, and Riahipour (2012) attempted to get the perspectives of language teachers and learners, regarding their views about the factors that may negatively affect the speaking performance of language learners. Their findings revealed that from the students' point of view, factors related to teachers, equipment and class utility are the three most demotivating ones as far as speaking skill is concerned. From the teachers' perspective, the three most demotivating factors are related to teachers, time, and classroom. Another study by Meshkat and Hassani (2012) examined demotivating factors in learning English from the learners' perspective. The results indicated that Iranian students considered lack of school facilities, overemphasis on grammar, long passages, and expectancy to use grammatically correct English in the classroom as strong sources of demotivation. Learning contents and materials and teachers' competence and teaching styles are moderate sources of demotivation. They also found significant differences between males' and females' perspectives regarding demotivational factors.

Tabatabaei and Molavi (2012) reported that factors such as teaching methods, inadequate class time, problems in understanding oral language, and lack of practice in real situation were essential demotivators among Iranian seminary students. Moreover, they found that more motivated students were at higher levels of general English proficiency. Rahman and Alimorad (2013) studied demotivation among Iranian high school students and concluded that reduced self-confidence was a leading demotivator. They further concluded that most of the demotivation is rooted in the way English teaching is viewed and practiced in public schools. However, most studies in Iranian context have focused on motivation (Alavi, 2004; Arai, 2004; Asghari, 1998; Fazel, 2003; Hasani, 2005; Neisi, 2007; Ramazanian, 1998; Roohani, 2001; Sakai \& Kikuchi, 2009; Samaie, 2006; Sedaghat, 2001).

Falout, Elwood, and Hood (2009) conducted a study on 900 university EFL learners to investigate demotivating factors in learning EFL in Japan, and the relationship between past demotivating experiences and present proficiencies. In their study, demotivating factors were grouped into three categories: external conditions of the learning environment, internal conditions of the learner, and reactive behaviors to demotivating experiences. Internal and reactive factors were shown to correlate with long-term EFL learning outcomes.

Chambers (1993) studied demotivation in the area of L2 learning and examined demotivated learners in four schools in Leeds, UK. The researcher administered a questionnaire to 191 students. Seven teachers also completed another questionnaire. Teachers defined demotivated students in the following ways: 1) lacking of enthusiasm, motivation, and concentration on the learning process, 2) lacking of self-confidence and eagerness in doing home works, and 3) distracting other students in class. Students considered teachers as the main source of demotivation, unlike teachers who did not perceive themselves as a demotivating factor. The students also reproached their teachers for: 1) having out of date teaching method, 2) giving insufficient description on lesson, 3) having bad temperate when they do not understand, and 4) not using up-to-date equipment.

In this line, Bednarova (2011) investigated the negative impact of demotivational factors on learners' motivation in learning English. The study was unique in discovering the source of demotivation from learners' perspective by providing their experiences in mislaying initial motivation and the reasons to cope with demotivation. The qualitative method was employed for gathering data. Based on the analysis of 54 learners' essays, the findings revealed that demotivation was a crucial problem that negatively affected students' motivation and behavior in learning English as a second language (ESL). The results also indicated that external factors were more demotivating than internal ones and that the teachers were the prominent element of demotivation that was perceived by learners.

Keblawi (2006) studied demotivation of Arab learners of English. The participants in this study were 294 Arab learners of English in years 9 and 10 (aged 15 and 16). The demotivating factors that students referred to were related to teachers. The demotivating factors were classified into two main groups: teachers' style (that is, the way they taught and presented the material to students), and personality traits (that is, the way they behaved with students). Furthermore, various other factors such as textbooks and evaluation system were also identified by learners as demotivating. Dornyei (2001) conducted a study of 50 secondary school pupils in Budapest who were studying either English or German as their second language. The data were collected through structured interviews. He identified the teacher, lack of self-confidence, negative attitudes toward the L2, the compulsory nature of L2 study, interference of other languages, negative attitudes towards the L2 community, attitudes of group members, the course book, and inadequate school facilities as nine demotivating factors.

Takako (2005) studied the influence of teachers on learners' motivation in an L2 classroom. The purpose of this paper was to survey existing research on teacher influence on learner motivation in L2 language classrooms. The findings 
showed that teachers have considerable influence on learners' motivation, and that several general implications exist pertinent to classroom practice. Mora Vázquez, Trejo Guzmán, and Roux Rodríguez (2010) conducted a small scale investigation into Mexican university students' language learning motivation. The participating students in this study identified teacher-specific motivational components and group-specific motivational components as the two most influential factors from their learning context in determining their L2 learning motivation levels.

Oxford (1998) carried out an investigation on 250 American students about their learning experiences. During the investigation, students were expected to comment on a variety of topics such as to "describe a situation in which you experienced conflict with a teacher" and "talk about a classroom in which you felt uncomfortable." Four types of demotivation factors were discovered: (a) the teacher's personal relationship with the students, (b) the teacher's attitude towards the course or the material, (c) style conflicts between teachers and students, (d) and the nature of the classroom activities. Many demotivators such as the teacher's lack of caring or favoritism, the teacher's lack of enthusiasm and sloppy management towards the course or the material, the conflicts about the degree of closure or seriousness of the class, and the amount of irrelevance and repetitiveness were found.

In the field of language teaching, Rudnai's (1996) and Dörnyei's (1998) studies were among the early attempts to investigate demotivation. In her investigation of why demotivated learners lost their motivation to study English, Rudnai (1996) conducted interviews with 15 students. Following Dörnyei’s motivation model (1998), she prepared interview guides covering demotivation at the language level, the learner level, and the learning situation level to find out if and why her participants had lost interest in English. Rudnai concluded that the most important elements her participants lacked concerned the learners' proficiency levels and learning situation levels.

Muhonen (2004) explored demotivational factors that discouraged students from learning the English language. 91 ninth-graders studying English at Finnish comprehensive school were asked to do a task. They were asked to tell in their own words about the issues at school that they felt had had a negative influence on their motivation to learn English. The demotivating factors that emerged from the answers were as follows: the teacher, learning material, learner characteristics, school environment, and learners' attitude towards the English language. Regarding gender, the comparison of demotivating factors among the males and the females revealed only slight differences.

Kikuchi and Sakai (2001) explored possible demotivating factors in high school English classes. 112 participants were asked to complete the questionnaire on the Internet. Using a principal axis factor analysis, they extracted five factors: (a) course books, (b) inadequate school facilities, (c) test scores, (d) non-communicative methods, and (e) teachers' competence and teaching styles. The results showed a statistically significant difference among the five factors. They concluded that their participants considered the factor concerning inadequate school facilities to be less demotivating than the other four factors. Recently, the term remotivation has been introduced in the field of L2, which refers to taking steps to bring back learners' motivation (Falout et al., 2009).

\section{Methodology}

\subsection{Design of the Study}

The design of the study is correlational, which is a subset of ex post facto designs. This design is used where the researcher does not have any control over the selection and manipulation of independent variables. In the studies using this design, the type or degree of relationship between two given variables is investigated instead of a cause-and-effect relationship.

\subsection{Participants}

The participants in this study were 96 high school students, learning English as a foreign language as an extracurriculum course six hours a week. They were female and male students at SAMA high school in Neyshabur in the final year of the three-year secondary school education between 17 to 18 years of age. This sample was selected from among twelve English classes. A total of over 150 high school students participated in extra-curriculum English classes. A stratified random sampling procedure was used to have three groups of 32 from the three majors. Each group comprised 16 females and 16 males. The stratified sampling was used to ensure that enough students of the two gender groups are represented in the sample. Table 1 shows the details of the population and sample. 
Table 1. The population and sample size

\begin{tabular}{lllll}
\hline Major & Population & \multicolumn{3}{l}{ Sample } \\
\cline { 2 - 5 } & Male & Female & Male & Female \\
\hline Humanities & 20 & 21 & 16 & 16 \\
Science & 22 & 29 & 16 & 16 \\
Mathematics & 25 & 33 & 16 & 16 \\
\hline
\end{tabular}

\subsection{Instruments}

\subsubsection{Reading Proficiency Test}

The test was derived from the reading section of the Cambridge Test of English Proficiency. This test incorporates three cloze texts with 24 items. The time for answering this test is 30 minutes. The participants' performance on this test was analyzed against the variables of the study, gender and major. The purpose of this comparison is to find out about the possible meaningful relationship among these variables. This is a standard test, and the reliability index of the questionnaire using Cronbach Alpha was 0.91. The test material is the same for all the test takers, but the items have been shuffled in a way to limit the chance of cheating on the exam.

\subsubsection{Demotivating Factor Questionnaire}

A demotivating factor questionnaire was administered in this study. This questionnaire includes the questions incorporating the nine factors, identified by Dornyei (1998), along with an item asking participants to write down any further possible factors they identify. A translated version, adapted from Sakai and Kikuchis' (2009) demotivation questionnaires, was employed in the present research limiting the alternatives to 1) agree and 2) disagree. This modification was done since the other alternatives seemed problematic and ambiguous for the high school language learners. The time to fill out the questionnaire was 15 minutes.

The data gathered through this questionnaire was analyzed against the participants' scores on the proficiency test to find out if their gender, major, and demotivators play a role in their reading test performance. It included 30 items like the following:

1. I seldom had chances to communicate in English.

2. Most of the lessons focused on grammar.

3. Most of the lessons were examination-oriented.

4. I was expected to use (or speak and write) grammatically correct English.

5. I was forced to memorize the sentences in the textbooks too often.

6. The pace of lessons was not appropriate.

7. I received poor grades on tests.

8. Teachers ridiculed students' mistakes.

The following factors, categorized by Dörnyei (1998), were also used in developing the questionnaire:

1. The teacher;

2. Inadequate school facilities;

3. Reduced self-confidence;

4. Negative attitude;

5. Compulsory nature of L2 study; 
6. Interference of another foreign language being studied;

7. Negative attitude towards L2 community;

8. Attitudes of group members; and

9. Course book.

\subsection{Data Collection Procedure}

The participants were briefed on the structures of the proficiency test and the demotivating factor questionnaire before their administration. They received the necessary explanations as to how to fill in the questionnaire and answer the test. The time for answering the reading proficiency test was 30 minutes and 15 minutes for completing the questionnaire.

\subsection{Data Analysis}

The participants' performance on the reading comprehension test was analyzed against the variables of the study, gender and major. The purpose of this comparison is to find out about the possible meaningful correlation among these variables. To this purpose, the Point-biserial correlation $\left(\mathrm{r}_{\mathrm{pbi}}\right)$ was used. This method of analysis is used when two sets of nominal and interval variables are concerned. Also, the Chi-square procedure was used. This procedure helps us analyze nominal variables in terms of their frequency of occurrence (Hatch \& Farhadi, 2001). The nominal variables of this study are gender and major.

\section{Results and Discussion}

Table 2 presents the frequency of each of demotives identified by the participants.

Table 2. Frequency of demotives

\begin{tabular}{lllllll}
\hline Demotive & Teacher & Facilities & $\begin{array}{l}\text { Reduced } \\
\text { confidence }\end{array}$ & Interference & $\begin{array}{l}\text { Negative } \\
\text { attitude }\end{array}$ & peer \\
\hline Freq. & 28 & 30 & 34 & 21 & 19 & 6 \\
\hline
\end{tabular}

As is evident from Table 2, the most common demotivating factor, reported by the participants is reduced confidence. Next come facilities and teacher as prominent sources of demotivation. The least common factor is the book. There is a meaningful relationship among these factors and the study variables, namely, major, gender, and reading comprehension, which are presented in the following sections. Table 3 displays the descriptive statistics of the reading test, with 9 and 19 as the lowest and highest scores respectively, and a standard deviation of 2.31.

Table 3. Descriptive statistics of the reading test

\begin{tabular}{llllll}
\hline & $\mathrm{N}$ & Minimum & Maximum & Mean & Std. Deviation \\
\hline Reading test & 96 & 9.00 & 19.00 & 14.19 & 2.31 \\
\hline
\end{tabular}

\subsection{The First Hypothesis}

Table 4 summarizes the details of the correlation of reading scores and teacher as a source of demotivation. 
Table 4. Correlation of reading scores and teacher factor

\begin{tabular}{llll}
\hline & & Reading & Teacher \\
\hline Reading & Pearson Correlation & 1 & $-.245^{*}$ \\
& $\mathrm{~N}$ & 96 & 96 \\
Sig. & & .016 \\
Teacher & Pearson Correlation & $-.245^{*}$ & 1 \\
& $\mathrm{~N}$ & 96 & 96 \\
& Sig. & .016 &
\end{tabular}

*. Correlation is significant at the 0.05 level (2-tailed).

The correlation is significant at a level of 0.05. This is to say that there is a significant relation between the teacher as a demotivating factor and the students' scores on reading comprehension test. As mentioned earlier, the researcher used a binary coding method for nominal values, with 1 for presence and 0 for absence of a factor. This correlation is negative, and this means when the teacher as a demotivating factor is not at play, the reading scores tend to be higher.

Table 5. Correlation of reading scores and self-confidence factor

\begin{tabular}{llll}
\hline & & Reading & Self-conf. \\
\hline Reading & Pearson Correlation & 1 & $-.291^{* *}$ \\
& $\mathrm{~N}$ & 96 & 96 \\
& Sig. & & .004 \\
Self-conf. & Pearson Correlation & $-.291^{* *}$ & 1 \\
& $\mathrm{~N}$ & 96 & 96 \\
& Sig. & .004 & \\
\hline
\end{tabular}

**. Correlation is significant at the 0.05 level (2-tailed).

A look at Table 5 makes it evident that the reading scores are in a significant relationship with the reported reduced self-confidence by the participants. This correlation has also a negative orientation, which means the absence of reduced self-confidence, as a demotivating factor, tends to lead to higher performance in reading comprehension. Among the six demotivating factors, analyzed in this study, only the two factors of teacher and reduced self-confidence were found significantly in relation with reading proficiency. Other factors, namely, facilities, interference, peer attitude, and course book were not found in significant relationship with reading proficiency.

\subsection{The Second Hypothesis}

The second hypothesis concerns the possible significant relationship between the two variables of educational field and demotivating factors. The analysis of the data proved no significant relationship between any of demotives and the participants' field at $p<0.05$. This suggests that demotivation is perceived generally the same for each of these groups. Table 6 shows the results. 
Table 6. Correlation of major and demotivating factors

\begin{tabular}{lllllllll}
\hline & & Major & Teacher & Facilities & Self-conf. & Interference & $\begin{array}{l}\text { Peer } \\
\text { attitude }\end{array}$ \\
\hline Major & Pearson & 1 & -.084 & -.055 & -0.53 & -.093 & -.096 & -.053 \\
& $\mathrm{~N}$ & 96 & 96 & 96 & 96 & 96 & 96 & 96 \\
& Sig. & & .415 & .594 & .606 & .370 & .352 & .610 \\
\hline
\end{tabular}

**. Correlation is significant at the 0.05 level (2-tailed).

\subsection{The Third Hypothesis}

The third hypothesis states that there is no significant relationship between the students' gender and their demotivating factors. In fact, the only significant relationship was found between peers' attitude and gender at $p<0.05$. As mentioned earlier, the nominal data of gender were indicated through 1 for female and 0 for male. Since the orientation of the correlation is positive, it means that peer negative attitude was generally a demotivating factor for female learners, but it was not an issue among male learners.

Table 6. Correlation of gender and peer attitude factor

\begin{tabular}{llll}
\hline & & Gender & Peer attitude \\
\hline Gender & Pearson Correlation & 1 & $.235^{*}$ \\
& $\mathrm{~N}$ & 96 & 96 \\
Peer attitude & Sig. & & .021 \\
& Pearson Correlation & $.235^{*}$ & 1 \\
& $\mathrm{~N}$ & 96 & 96 \\
& Sig. & .021 & \\
\hline
\end{tabular}

*. Correlation is significant at the 0.05 level (2-tailed).

\subsection{Other Findings}

The analysis revealed that there is a significant relation between performance on the reading test and field of study. This correlation, details of which are displayed in Table 7, indicates that math students generally outperformed science students, and science students outperformed humanities students in the reading test.

Table 7. Correlation of reading performance and field of study

\begin{tabular}{llll}
\hline & Major & Reading scores \\
\hline Major & Pearson Correlation & 1 & $.211^{*}$ \\
& $\mathrm{~N}$ & 96 & 96 \\
& $\mathrm{Sig}$. & & .039 \\
Reading & Pearson Correlation & $.211^{*}$ & 1 \\
Performance & $\mathrm{N}$ & 96 & 96 \\
& Sig. & .039 & \\
& &
\end{tabular}

*. Correlation is significant at the 0.05 level (2-tailed).

However, male participants in the study displayed a slightly better performance on the test, as shown in Table 8. 
Table 8. Descriptive statistics for males and females on the reading test

\begin{tabular}{llll}
\hline & $\mathrm{N}$ & Mean & Std. Deviation \\
\hline Female & 48 & 14 & 2.35 \\
Male & 48 & 14.31 & 2.27 \\
\hline
\end{tabular}

The analysis revealed that language teacher, as a common demotivating factor, is in significant relation with the participants' performance. This relationship suggests that those students with a lower performance viewed teacher as one major issue. The possibility that teacher might have had an effect on this low performance can be subject to more inquiry.

In the methodology section, it was stated that Dörnyei (1998) categorized nine factors in his questionnaire. However, since the three factors of negative attitude, compulsory nature of L2 study, and negative attitude towards L2 community did not get any significant rating by the participants, they were excluded from the analysis. Reduced selfconfidence was reportedly as the most significant demotivating factor in this study, with a frequency of 34 , which is more than one-third of the participants. This factor is also in relation with a low performance on the reading test, with a correlation coefficient of $-.291^{* *}$. This correlation, which is significant at a level of 0.05 , suggests that for lower achieving students this factor was an issue.

The third finding concerns the gender and peer attitude. Female participants signaled peer attitude as a factor contributing to demotivation. This attitude is mostly realized in peers' reactions to their performance in the class or on the tests. Peer pressure is not an unknown issue in the field, but its relation to female learners has not been documented previously. Finally, the participants' field of study was found to be in a meaningful relation to their performance. Table 8 indicates that males outperformed females by a narrow, and yet insignificant margin. However, the participants' field of study, as the second independent variable of the study, proved to be in significant relation with their performance, in the way that math students outperformed science students, and they both outperformed humanities students.

The first finding is related to the role of teacher as a demotive and reading comprehension. It was found that teacher's effect on learning in terms of motivation, especially reading comprehension, is significant. In many studies on demotivation, teacher has been reported as the main factor of demotivation (Chambers, 1993; Gorham \& Christophel, 1992). The analysis revealed that teacher as a common demotivating factor is in relation with participants' performance. This correlation does not indicate that this factor is or is not a demotivating factor, which previous studies and Table 2 attest to, but this correlation suggests that those students with a lower performance viewed teacher as one major issue. The possibility that teacher might have had an effect on this low performance can be subject to more inquiry.

The second finding which concerns the second research question is that in spite of some variation, educational field of students has nothing to do with demotivation. This suggests that language learners in different fields share the same demotives. Besides these findings, which were addressed by the research questions, there was also another relation present. That is the relation of field of study and reading comprehension test performance. Reading is an analytical process. Secada (1992) stated that there is sufficient evidence to conclude that language proficiency, no matter how it is measured, is related to mathematics achievement. This may be an explanation to why math and science students had better performance in reading comprehension.

Another finding of this study addressed by the third research question is about the gender and demotivation. As long as peer attitude is concerned, female learners seem to experience more pressure from their classmates. Research literature on gender and motivation is not quite conclusive; some have reported integrative and instrumental orientations more powerful by female learners (Dörnyei \& Clement, 2001; Kissau, 2006; Kormos \& Csizer, 2008; Mori \& Gobel, 2006; Yang, 2003). There are few researches on demotivation across gender groups. Lee and Lee (2011) investigated differences in perception of demotivating factors according to gender and general English proficiency. The results revealed that male students had more negative attitudes and low proficient learners were the most demotivated ones. 
Another finding is the fact that reduced confidence, lack of enough facilities, and teacher are three major demotive among other factors. Dörnyei (1998) categorized nine factors in his questionnaire. However, since the three factors of negative attitude, compulsory nature of L2 study, and negative attitude towards L2 community did not get any significant rating by the participants, they were excluded from the analysis. The findings of this study showed that reduced self-confidence was reportedly the most significant demotivating factor in this study, with a frequency of 34, which is more than one-third of the participants. This factor is also in relation with a low performance on the reading test, with a correlation coefficient of $-.291^{* *}$. This correlation, which is significant at a level of 0.01 suggests that for lower achieving students this factor was an issue. The same finding has been reported by Rahman and Alimorad (2013); they concluded that reduced self-confidence was a leading demotivator. Although in many research studies in this field teacher has been viewed as the biggest factor of demotivation (Chambers, 1993; Gorham \& Millette, 1997), it was not top as the first factor here. However, reduced self-confidence, which was found the most frequent demotive by students, may be attributable to language teachers. Since interaction is highly important in language classrooms, lack of confidence can easily override a student's eagerness to participate in class activities.

\section{Conclusion}

The four variables in this research were gender, educational field, reading proficiency, and demotivating factors. This study adds to the literature on demotivating factors shared by quite a number of Iranian language learners, and its dependence on their gender and educational field. As stated before, there is an ample body of research on gender and motivation; however, the findings tend to diverge as long as gender is concerned. This issue is bigger regarding demotivation. We tried to fill this gap to the extent and scope of this study. The issue of demotivation and more specifically this question that what demotives are shared in our local education is a new area of inquiry. This question that which factor is in a meaningful relationship with reading proficiency and in which way, was another concern of this study. There was another finding apart from those addressed by the research questions; the correlation between reading proficiency and field of study.

There are some implications for language pedagogy and general education, set forth by this study. The issue of demotivation is a pervasive phenomenon. As it was concluded that the main factor to demotivate a learner is reduced self-confidence, teachers and educators should help find the source of this issue. It was revealed in this study that teacher and teaching facilities are the second major demotives, which by themselves may have had an effect on reduced self-confidence. Every act of a teacher in the classroom can be motivating, and of course demotivating. It may not be readily feasible to improve teaching aids and bring state-of-the-art facilities to the classroom, but teachers can have more informed decisions and actions during a class period.

Another implication is that peer pressure should be reduced by promoting a cooperative class atmosphere, especially with female learners. Cooperative approach to learning may help reduce this pressure. Cooperative learning can be characterized as a social process, in which knowledge is acquired through the successful interaction between the group members. This takes some pre-requisites to happen such as individual accountability by students, social skills, interaction, positive interdependence, and group processing. The latter condition "group processing" could be a challenge to some language teachers. It seems necessary that teachers promote a more cooperative atmosphere and reduce the competitiveness of learning tasks to decrease demotivating factors to learn English.

\section{Suggestions for Further Research}

In this research, some questions came up which can be subject to further research. The first potential area for further studies is the link between self-confidence and each of other demotivating factors. Reduced self-confidence was found to be the most common demotive by the participants. Especially, the role of teacher in reduced self-confidence could lead to constructive findings. Another theme for more research could be why peer-pressure is a significant issue by female learners and how. Answering these questions can lead to a better understanding of what demotivation is and how it operates in learning. According to Dörnyei (2007), if learners form cliques and subgroups that are hostile to each other and resist any cooperation, the overall climate will be stressful for teachers and students alike, and learning effectiveness is likely to plummet.

Another suggestion for further research could be investigating the effects of introducing cooperative learning approach tasks on reduced confidence and peer pressure as main learners' variables, which are demotives at the same time. Furthermore, it is important that a teacher has at his/her disposal a number of motivating tasks and strategies. After all, teachers are the main actors in the classroom and can take more active roles in motivating students in language 
classrooms. As Dörnyei (2007) asserts, language teachers are by definition group leaders and as such they determine every facet of classroom life. Further, as Riazi (2005) explains, the centralized system of education assigns the same textbooks, the same teaching methods, and the same testing procedures to all parts of the country regardless of their geographical, social and cultural differences. These findings highlight the role of teachers as well as a need for more dynamic teaching and testing technics to help increase motivation.

As many other studies in this field, this study addressed demotivation and its factors from the viewpoint of learners. It was reveled in this study that teachers are more likely to attribute students' demotivation to performance-related factors, but students attribute more of their demotivation to teacher behavior, such as poor presentational skills, and lack of enthusiasm. It can be very helpful to see how this different viewing of the same construct is connected to what really happens in the class time between teacher and students, and to find out how different and similar their views are in terms of demotivation.

\section{References}

Alavi, S. (2004). A multi-variate causal model of motivation in second/foreign language learning. Unpublished doctoral dissertation, Shiraz University, Iran.

Arai, K. (2004). What demotivates language learners? Qualitative study on demotivational factors and learners' reactions. Bulletin of Toyo Gakuen University, 12, 39-47.

Asghari, N. (1998). The role of intrinsic, extrinsic motivation and amotivation in Iranian students of English language. Unpublished master's thesis, Shiraz University, Iran.

Bednarova, N. (2011). De-motivating influences for learning English among students on lower stages of 8-year Grammar School (Diploma thesis). University of Masaryk. http://is.muni.cz/th/237053/pedf_m/Bednarova_diploma_thesis.pdf

Chambers, G. (1993). Taking the 'de' out of demotivation. Language Learning Journal, 7, 13-16.

Christophel, D., \& Gorham, J. (1995). A test-retest analysis of student motivation, teacher immediacy and perceived sources of motivation and demotivation in college classes. Communication Education, 44(4), 292-306. doi: $\underline{10.1080 / 03634529509379020}$

Crookes, G., \& Schmidt, R. W. (1991). Motivation: Reopening the research agenda. Language Learning, 41, 469-512. http://dx.doi.org/10.1111/j.1467-1770.1991.tb00690.x

Dörnyei, Z. (1998). Motivation in second and foreign language learning. Language Teaching, 31(3), 117-135. http://dx.doi.org/10.1017/S026144480001315X

Dörnyei, Z. (2001). Motivational strategies in the language classroom. Cambridge: Cambridge University Press.

Dörnyei Z. (2007). Creating a motivating classroom environment. In Cummins J., Davison C. (eds), International handbook of English language teaching. Springer International Handbooks of Education, Vol, 15. Springer, Boston, MA.

Dörnyei, Z., \& Clement, R. (2001). Motivational characteristics of learning different target languages: Results of a nationwide survey. In Z. Dornyei, \& R. Schmidt (Eds.), Motivation and second language acquisition. Honolulu, HI: University of Hawaii Press.

Fazel, E. (2003). Effects of instrumental/integrative motivation on oral proficiency among Iranian female students of English at Shiraz University language center. Unpublished master's thesis, Shiraz University, Iran.

Falout, J., Elwood, J., \& Hood, M. (2009). Demotivation: Affective states and learning outcomes. System, 37(3), 403417. http://dx.doi.org/10.1016/j.system.2009.03.004

Gorham, J., \& Christophel, D. (1992). Students' perceptions of teacher behaviors as motivating and demotivating factors in college classes. Commutation Quarterly, 40(3), 239-252. doi:10.1080/01463379209369839

Gorham, J., \& Millette, D. (1997). A comparative analysis of teacher and student perceptions of sources of motivation and demotivation in college classes. Communication Education, 46(4), 245-261. doi:10.1080/03634529709379099 
Hasani, H. (2005). The relationship between intrinsic, extrinsic motivation and Iranian EFL students' gender, level of university instruction and EFL proficiency. Unpublished master's thesis, Shiraz University, Iran.

Hatch, E., \& Farhady, H. (1981). Research design and statistics. Tehran: Rahnama.

Heidari Soureshjani, K., \& Riahipour, P. (2012). Demotivating factors on English speaking skill: A study of EFL language learners and teachers' attitudes. World Applied Sciences Journal, 17(3), 327-339. https://pdfs.semanticscholar.org/0d96/6c599fcc295d5833b7b6aebfab0e419057f2.pdf

Keblawi, F. (2006). Demotivation among Arab learners of English as a foreign language. AlMaktoum Institute for Arabic and Islamic Studies University of Aberdeen. http://www.readingmatrix.com/conference/pp/proceedings2005/keblawi.pdf

Kikuchi, K., \& Sakai, H. (2001). Japanese learners' demotivation to study English: A survey study. Unpublished manuscript.

Kissau, S. (2006). Gender differences in motivation to learn French. Canadian Modern Language Review/La Revue canadienne des languesvivantes, 62(3), 401-422. doi: 10.3138/cmlr.62.3.401

Kormos, J., \& Csizér, K. (2008). Age-related differences in the motivation of learning English as a 464 foreign language: Attitudes, selves, and motivated learning behavior. Language Learning, 58(2), 327-355. https://doi.org/10.1111/j.1467-9922.2008.00443.x

Lee, J., \& Lee, C. (2011). Demotivation factors in learning English for elementary school students. Primary English Education, 17(1), 327-355.

Littlewood, W. (1996). Autonomy: An anatomy and a framework. System, 24(4), 427-435. https://doi.org/10.1016/S0346-251X(96)00039-5

Meshkat, M., \& Hassani, M. (2012). Demotivating factors in learning English: The case of Iran. Social and Behavioral Sciences, 31, 745-749. doi:10.1016/j.sbspro.2011.12.134

Mora Vázquez, A., Trejo Guzmán, N. P., \& Roux Rodríguez, R. (2010). A small scale investigation into Mexican university students' language learning motivation. Actualidades Investigativas en Educación, 10(1), 1-15. http://revista.inie.ucr.ac.cr/articulos/1-2010/archivos/scale.pdf

Mori, S., \& Gobel, P. (2006). Motivation and gender in Japanese EFL classroom. System, 34(2), 194-210. https://doi.org/10.1016/j.system.2005.11.002

Muhonen, J. (2004). Second language demotivation: factors that discourage pupils from learning the English language. Unpublished Pro Gradu Thesis. University of Jyväskylä, Department of Languages.

Oxford, R. L. (1998). The unraveling tapestry: Teacher and course characteristics associated with demotivation in the language classroom. Demotivation in foreign language learning. Paper presented at the TESOL '98 Congress, Seattle, WA, USA.

Oxford, R., \& Shearin, J. (1994). Language learning motivation: Expanding the theoretical framework. Modern Language Journal, 78(1), 12-28. http://dx.doi.org/10.2307/329249

Rahman, S., \& Alimorad, A. (2013). Demotivating factors affecting Iranian high school students' English learning. Researching Cultures of Learning, Palgrave Macmillan, A division of Macmillan Publishers Limited. pp.308-327. http://works.bepress.com/zahra_alimorad/6/

Neisi, S. (2007). Relationship between self-esteem, achievement motivation, FLCA and EFL learners' academic performance. Unpublished master's thesis, Shiraz University, Iran.

Ramazanian, M. (1998). The motivation for language learning among Shiraz University undergraduate students of English as a foreign language. Unpublished master's thesis, Shiraz University, Iran.

Riazi, A. M. (2005). The four language stages in the history of Iran. In A. M. Y. Lin \& P. W. Martin (Eds.). Decolonization, globalization: Language in education policy and practice. (pp. 100-116). UK: Multilingual Matters Ltd. 
Roohani, A. (2001). An investigation into EFL students' motivation in Shiraz state and Islamic Azad University. Unpublished master's thesis, Shiraz University, Iran.

Rudnai, Z. (1996). Demotivation in learning English among secondary school students in Budapest. Unpublished master thesis. Eotvos Lorand University, Budapest Hungary.

Sakai, K., \& Kikuchi, H. (2009). An analysis of demotivators in the EFL classroom. System, 37(1), 57-69. https://doi.org/10.1016/j.system.2008.09.005

Samaie, M. (2006). A critical discourse analysis of Gardner's theory of attitudes and motivation. Unpublished doctoral dissertation, Shiraz University, Iran.

Scarcella, R., \& Oxford, R. L. (1992). The tapes of language learning: The individual in the communicative classroom. Boston: Heinle\& Heinle.

Secada, W. G. (1992). Race, ethnicity, social class, language, and achievement in mathematics. In D.A. Grouws (Ed.), Handbook of research on mathematics teaching and learning (pp. 623-660). New York, NY: MacMillan.

Sedaghat, M. (2001). The effects of attitude, motivation (instrumental and integrative) and proficiency level on the use of listening comprehension strategies by Iranian female EFL students. Unpublished master's thesis, Shiraz University, Iran.

Tabatabaei, O., \& Molavi, A. (2012). Demotivating factors affecting EFL learning of Iranian seminary students. International Education Studies, 5(1), 181-190. doi:10.5539/ies.v5n1p181

Takako, T. (2005). Teacher influence on learner motivation. Osaka Jogakuin College Kiyo, 35, 49-58. http://www.wilmina.ac.jp/ojc/kiyo_2005/kiyo_35_PDF/2005 06.pdf

Vallerand, R. J., \& Ratelle, C. F. (2002). Intrinsic and extrinsic motivation: A hierarchical model. In E. L. Deci, E.L \& R. M. Ryan (Eds.) Handbook of self-determination research (37-63). Rochester, NY: University of Rochester Press.

Warden, C., \& Lin, H. J. (2000). Existence of integrative motivation in Asian EFL setting. Foreign Language Annals, 33(5), 535-547. doi:10.1111/j.1944-9720.2000.tb01997.x

Yang, J. S. R. (2003). Motivational orientations and selected learner variables of East Asian language learners in the United States. Foreign Language Annals, 36(1), 44-56. https://doi.org/10.1111/j.1944-9720.2003.tb01931.x 